\title{
A GOITRE SURVEY IN THE VALE OF GLAMORGAN
}

\author{
BY \\ W. R. TROTTER \\ Medical Unit, University College Hospital Medical School, London
}

A. L. COCHRANE, I. T. BENJAMIN, AND W. E. MIALL
Medical Research Council, Pneumoconiosis Research Unit, South Wales
AND
D. EXLEY
Unit for Research in Cell Metabolism, Medical Research Council, Oxford

The object of most previous goitre surveys has been to determine the prevalence of the condition in different areas, and to compare the results with some other finding, such as the iodine content of local water supplies. The purpose of the present survey was somewhat different. The number of persons with goitre was ascertained in a defined area in South Wales (Cochrane, Miall, and Clarke, 1956), where goitre was known to be fairly common (Davies and Rogers, 1940). These subjects were then compared in various respects with matched nongoitrous controls drawn at random from the same population. The object of the investigation was thus to define the factors which determine the susceptibility of individuals to goitre within a population living in a fairly uniform environment, rather than the factors which are responsible for regional differences in overall prevalence. Although the results of this survey are far from conclusive, the methods used may be of interest, and might be worth developing in another context.

\section{METHODS}

During the course of a chest $x$-ray survey of the Vale of Glamorgan (Cochrane and others, 1956), all persons attending (comprising 95 per cent. of the defined population) were asked whether they "had ever suffered from goitre". The meaning of this phrase seemed to be generally understood. All those who answered affirmatively were then visited independently by two of us (W.E.M. and W.R.T.) and examined clinically. The second observer (W.R.T.) also visited an equal number of control subjects, selected by random numbers from the same population, and matched for age and sex with the goitre group. Both goitre and control groups were then visited by a lay assistant (T.B.), unaware of the clinical findings, who took a complete history of each subject's previous place of residence, with the type of water supply, and of his past and present consumption of fish, shellfish, and laver-bread (a local product made from sea-weed, very rich in iodine) The group of women with large non-toxic goitres was then investigated in more detail by the collection of samples from as many past or present sources of water supply as possible, which were analysed for iodine by one of us (D.E.). Goitre in the parents and sibs of goitre cases and controls was also ascertained by history, though relatives were not examined.

\section{RESULTS}

(1) Assessment of Thyroid States.-Goitre can only be defined in arbitrary terms. In the present survey, two grades of thyroid enlargement were recognized; large, meaning that there was an easily visible goitre, and small, meaning that the thyroid was definitely enlarged to palpation but did not present as an obvious abnormality.

We had also intended to ascertain the prevalence of thyrotoxicosis. In practice, however, this proved to be impossible, because so many of the likely cases had been treated in the past (usually by thyroidectomy) and a firm retrospective diagnosis could not be made, even with the help of hospital records. For the purpose of analysis all cases in which past or present thyrotoxicosis was a possibility have been grouped together under the heading of "possibly thyrotoxic".

Since the definition of goitre is necessarily arbitrary it was not possible to test for "observer error", for when two or more observers differ we have no means of deciding whose judgment is correct. The 
differences recorded by the two clinical observers in the present survey are presented in Table I. As might be expected, there are considerable discrepancies in the assessment of the presence or absence of thyrotoxicosis and in the assessment of goitre size. It is, however, apparent that, whenever one observer diagnosed a large non-toxic goitre, the other observer always agreed that some thyroid abnormality was present. For this reason the subjects with large non-toxic goitres were used for intensive study, the remaining thyroid abnormalities providing supporting evidence. The second observer's assessment was used throughout, since he had also examined the control series.

TABLE I

ASSESSMENT OF THYROID STATUS IN FEMALES BY TWO INDEPENDENT OBSERVERS

\begin{tabular}{|c|c|c|c|c|c|c|}
\hline & & \multicolumn{4}{|c|}{ Observer A } & \multirow[b]{2}{*}{ Total } \\
\hline & & $\begin{array}{l}\text { Large } \\
\text { Non- } \\
\text { toxic } \\
\text { Goitre }\end{array}$ & $\begin{array}{l}\text { Small } \\
\text { Non- } \\
\text { toxic } \\
\text { Goitre }\end{array}$ & $\begin{array}{l}\text { History } \\
\text { of } \\
\text { Goitre: } \\
\text { Thyroid } \\
\text { not now } \\
\text { Palpable }\end{array}$ & $\begin{array}{c}\text { Possible } \\
\text { Thyro- } \\
\text { toxicosis }\end{array}$ & \\
\hline \multirow{4}{*}{$\underset{\text { B }}{\text { Observer }}$} & $\begin{array}{cc}\text { Large } & \text { Non- } \\
\text { toxic } & \text { Goitre }\end{array}$ & 32 & 9 & 0 & 6 & 47 \\
\hline & $\begin{array}{rr}\text { Small } & \text { Non- } \\
\text { toxic } & \text { Goitre }\end{array}$ & 12 & 37 & 11 & 24 & 84 \\
\hline & $\begin{array}{l}\text { History of } \\
\text { Goitre: Thy- } \\
\text { roid not now } \\
\text { Palpable } . .\end{array}$ & 0 & 10 & 16 & 9 & 35 \\
\hline & $\begin{array}{c}\text { Possible Thy- } \\
\text { rotoxicosis }\end{array}$ & 2 & 4 & 1 & 51 & 58 \\
\hline \multicolumn{2}{|l|}{ Total } & 46 & 60 & 28 & 90 & 224 \\
\hline
\end{tabular}

(2) INCIDENCE OF GoITRE.-The diagnosis made by the second observer in the goitre and control groups are recorded in Table II.

TABLE II

DIAGNOSES MADE ON "GOITRE” AND "CONTROL" GROUPS

\begin{tabular}{|c|c|c|c|c|c|c|}
\hline \multirow{2}{*}{$\frac{\text { Sex }}{\text { Group } \ldots}$} & \multirow{2}{*}{ - } & & \multicolumn{2}{|c|}{ Male } & \multicolumn{2}{|c|}{ Female } \\
\hline & & .. & Goitre & Control & Goitre & Control \\
\hline \multirow{5}{*}{ Diagnosis } & \multirow{2}{*}{$\begin{array}{l}\text { Non-toxic } \\
\text { Goitre }\end{array}$} & Large & 10 & 1 & 47 & 4 \\
\hline & & Small & 10 & 5 & 84 & 78 \\
\hline & \multicolumn{2}{|c|}{$\begin{array}{l}\text { History of Goitre: } \\
\text { Thyroid not now } \\
\text { Palpable .. }\end{array}$} & 2 & 0 & 35 & 1 \\
\hline & \multicolumn{2}{|c|}{$\begin{array}{l}\text { Possible Thyro- } \\
\text { toxicosis.. } \\
\text { Refused or Moved } \\
\text { away from Area }\end{array}$} & $\begin{array}{l}5 \\
0\end{array}$ & $\begin{array}{l}0 \\
0\end{array}$ & $\begin{array}{r}58 \\
2\end{array}$ & $\begin{array}{r}10 \\
9\end{array}$ \\
\hline & \multicolumn{2}{|l|}{ No Goitre } & 0 & 21 & 0 & 124 \\
\hline Total & $\ldots$ & $\ldots$ & 27 & 27 & 226 & 226 \\
\hline
\end{tabular}

It will be seen that some thyroid abnormality was noted in about 43 per cent. of the control group. Since these controls were a random sample of the remainder of the population, this finding enabled us to calculate the total prevalence of large goitres in the female population of the Vale of Glamorgan (Table III). The figures for males, about one-fifth of those for females, were too small for a reliable estimate.

TABLE III

ESTIMATED PREVALENCE OF LARGE GOITRE IN THE FEMALE POPULATION OF THE VALE OF GLAMORGAN

\begin{tabular}{|c|c|c|c|c|c|}
\hline $\begin{array}{l}\text { Age } \\
\text { Group } \\
\text { (yrs) }\end{array}$ & $\begin{array}{c}\text { Total } \\
\text { No. of } \\
\text { Females }\end{array}$ & $\begin{array}{c}\text { No. with } \\
\text { Large } \\
\text { Goitres } \\
\text { in Goitre } \\
\text { Group }\end{array}$ & $\begin{array}{c}\text { Estimated } \\
\text { No. with } \\
\text { Large Goitre } \\
\text { in Rest of } \\
\text { Population }\end{array}$ & $\begin{array}{l}\text { Total } \\
\text { with } \\
\text { Large } \\
\text { Goitre }\end{array}$ & $\begin{array}{l}\text { Prevalence } \\
\text { Per cent. }\end{array}$ \\
\hline $\begin{array}{l}15- \\
25- \\
35- \\
45- \\
55- \\
65- \\
75-\end{array}$ & $\begin{array}{l}369 \\
464 \\
403 \\
439 \\
339 \\
219 \\
109\end{array}$ & $\begin{array}{r}1 \\
6 \\
1 \\
11 \\
14 \\
6 \\
8\end{array}$ & $\begin{array}{c}- \\
\overline{7} \\
7 \cdot 4 \\
13 \cdot 0 \\
8 \cdot 5 \\
-\end{array}$ & $\begin{array}{r}1.0 \\
6.0 \\
1.0 \\
18.4 \\
27 \cdot 0 \\
14.5 \\
8.0\end{array}$ & $\begin{array}{l}0 \cdot 3 \\
1 \cdot 3 \\
0 \cdot 3 \\
4 \cdot 2 \\
8 \cdot 0 \\
6 \cdot 6 \\
7 \cdot 3\end{array}$ \\
\hline Total & 2,342 & 47 & $28 \cdot 9$ & $75 \cdot 9$ & $3 \cdot 2$ \\
\hline
\end{tabular}

Those cases of goitre in which the paired control also had an abnormal thyroid were excluded from the subsequent analysis.

(3) Prevalence of Goitre amongst Relatives. Table IV (overleaf) shows the higher prevalence of goitre in the sibs, children, and parents of goitrous subjects than of control subjects. There are at least three possible explanations for this:

(a) Greater awareness of goitre by those who themselves possess one;

(b) Tendency of members of a family to be exposed to similar environmental conditions;

(c) Inheritance of a factor which increases susceptibility to goitre.

Our data do not enable us to distinguish between these possibilities. However, one negative conclusion can be drawn. Neither among the subjects with goitre nor among the controls is there any tendency for goitre prevalence in sibs to exceed that in parents, as it would be expected to do if susceptibility to goitre was conveyed by a recessive gene. This accords with the conclusions of Martin and Fisher $(1945,1951)$ and contrasts with their findings in toxic diffuse goitre. The approximately equal consanguinity rate in the parents of those with and without goitre points in the same direction.

The total number of sibs was slightly greater in the goitre than the control group. Among the subjects with large goitres the difference is, however, 
TABLE IV

FAMILIAL OCCURRENCE OF GOITRE (MALE AND FEMALES)

\begin{tabular}{|c|c|c|c|c|c|c|c|c|c|c|c|c|c|c|c|c|c|c|c|}
\hline \multirow{4}{*}{ Diagnosis } & \multirow{4}{*}{ Group } & \multirow{4}{*}{$\begin{array}{c}\text { No. } \\
\text { of } \\
\text { Cases }\end{array}$} & \multicolumn{17}{|c|}{ Relations } \\
\hline & & & \multicolumn{3}{|c|}{ Brothers } & \multicolumn{3}{|c|}{ Sisters } & \multicolumn{3}{|c|}{ Sons } & \multicolumn{3}{|c|}{ Daughters } & \multirow{2}{*}{\multicolumn{2}{|c|}{$\begin{array}{c}\text { Father } \\
\text { with } \\
\text { Abnormal } \\
\text { Thyroid }\end{array}$}} & \multirow{2}{*}{\multicolumn{2}{|c|}{$\begin{array}{l}\text { Mother } \\
\text { with } \\
\text { Abnormal } \\
\text { Thyroid }\end{array}$}} & \multirow{3}{*}{$\begin{array}{c}\text { Parents' } \\
\text { First } \\
\text { Cousins }\end{array}$} \\
\hline & & & \multirow{2}{*}{ Total } & \multicolumn{2}{|c|}{$\begin{array}{l}\text { Abnormal } \\
\text { Thyroid }\end{array}$} & \multirow{2}{*}{ Total } & \multicolumn{2}{|c|}{$\begin{array}{l}\text { Abnormal } \\
\text { Thyroid }\end{array}$} & \multirow{2}{*}{ Total } & \multicolumn{2}{|c|}{$\begin{array}{l}\text { Abnormal } \\
\text { Thyroid }\end{array}$} & \multirow{2}{*}{ Total } & \multicolumn{2}{|c|}{$\begin{array}{c}\text { Abnormal } \\
\text { Thyroid }\end{array}$} & & & & & \\
\hline & & & & No. & $\begin{array}{c}\text { Per } \\
\text { cent. }\end{array}$ & & No. & $\begin{array}{c}\text { Per } \\
\text { cent. }\end{array}$ & & No. & $\begin{array}{c}\text { Per } \\
\text { cent. }\end{array}$ & & No. & $\begin{array}{c}\text { Per } \\
\text { cent. }\end{array}$ & No. & $\begin{array}{c}\text { Per } \\
\text { cent. }\end{array}$ & No. & $\begin{array}{c}\text { Per } \\
\text { cent }\end{array}$ & \\
\hline \multirow{2}{*}{$\begin{array}{l}\text { Large } \\
\text { Goitre }\end{array}$} & Goitre & 36 & 95 & 3 & $3 \cdot 2$ & 77 & 12 & $15 \cdot 6$ & 42 & 0 & 0 & 31 & 3 & $9 \cdot 7$ & 2 & $5 \cdot 6$ & 5 & $13 \cdot 9$ & 1 \\
\hline & Control & 36 & 90 & 1 & $1 \cdot 1$ & 76 & 4 & $5 \cdot 3$ & 45 & 0 & 0 & 41 & 3 & $7 \cdot 3$ & 1 & $2 \cdot 8$ & 0 & 0 & 0 \\
\hline \multirow{2}{*}{$\begin{array}{c}\text { AllThyroid } \\
\text { Abnor- } \\
\text { malities }\end{array}$} & Goitre & 145 & 327 & 7 & $2 \cdot 1$ & 294 & 47 & $16 \cdot 0$ & 144 & 1 & $0 \cdot 7$ & 161 & 24 & $14 \cdot 9$ & 5 & $3 \cdot 5$ & 26 & $18 \cdot 0$ & 2 \\
\hline & Control & 145 & 291 & 1 & $0 \cdot 3$ & 271 & 10 & $3 \cdot 7$ & 144 & 1 & 0.7 & 129 & 4 & $3 \cdot 1$ & 1 & 0.7 & 6 & $4 \cdot 1$ & 3 \\
\hline
\end{tabular}

quite trivial, and we do not therefore attach much importance to this finding.

(4) Place of Residence and Water Supply.Records were obtained, in both goitre and control cases, of the place of residence during the years from birth up to the time the goitre was first noticed, or an equivalent period in the case of controls; and the type of water supply in use during the same periods. Table $\mathrm{V}$ was constructed by adding together the number of years lived by each subject, inside or outside the Vale, with different types of water supply. Table V shows that more of the relevant years were spent in the Vale by the subjects with goitre than by the controls. This suggests that people living in the Vale are exposed to some goitrogenic factor which is on the average less potent in the rest of the country. Further breakdown of the results by type of water supply suggests that rain water, both inside and outside the Vale, and well water inside the Vale, may be in some way goitrogenic. The issue is, however, complicated by the fact that mains water was used during most of the time spent outside the Vale. Hence it is quite possible that the goitrogenic factor in the Vale was not connected at all with water supply, it being merely a coincidence that until recently mains water was rarely available there.

(5) IODINE INTAKe FROM WATER.-Inconclusive though they are, the data in Table $\mathrm{V}$ would be compatible with the hypothesis that the goitrogenic factor in the Vale was the low iodine content of the water supply, if the following assumptions are made:

(a) That rain water, inside and outside the Vale is equally deficient in iodine;

(b) That well water from the Vale contains lesso iodine than well water elsewhere;

(c) That mains water in the Vale contains less iodine than mains water elsewhere.

To test these assumptions, samples of water were obtained from all the sources used by the women with large goitres and their matched controls. These samples were than analysed for iodine by one of us (D.E.). The results are shown in Table VI (opposite). From these data the average weekly intake of iodine from water (assuming a daily consumption of 2 litres) was then calculated for the group of women with large goitres, and for their controls. This showed

TABLE V

NUMBER OF YEARS INSIDE OR OUTSIDE THE VALE OF GLAMORGAN, AND TYPE OF WATER SUPPLY, BEFORE THE ONSET OF GOITRE (OR AN EQUIVALENT PERIOD IN THE CASE OF CONTROLS)

\begin{tabular}{|c|c|c|c|c|c|c|c|c|c|c|c|}
\hline \multirow{3}{*}{\multicolumn{2}{|c|}{ Diagnosis }} & \multirow{3}{*}{ Group } & \multicolumn{8}{|c|}{ Source of Water Supply } & \multirow{3}{*}{$\begin{array}{l}\text { Total } \\
\text { Years }\end{array}$} \\
\hline & & & \multicolumn{2}{|c|}{ Rain } & \multicolumn{2}{|c|}{ Well } & \multicolumn{2}{|c|}{ Mains } & \multicolumn{2}{|c|}{ All Sources } & \\
\hline & & & Vale & Other & Vale & Other & Vale & Other & Vale & Other & \\
\hline \multirow{2}{*}{ Large Goitre } & & Goitre & 158 & 29 & 295 & 10 & 57 & 187 & 510 & 226 & 736 \\
\hline & & Control & 130 & .12 & 115 & 75 & 33 & 371 & 278 & 458 & 736 \\
\hline \multirow{2}{*}{\multicolumn{2}{|c|}{ All Thyroid Abnormalities }} & Goitre & 548 & 46 & 845 & 180 & 242 & 940 & 1,635 & 1,166 & 2,801 \\
\hline & & Control & 406 & 12 & 532 & 182 & 232 & 1,437 & 1,170 & 1,631 & 2,801 \\
\hline
\end{tabular}


that the women with large goitres had a mean weekly intake of $33.5 \mu \mathrm{g}$. iodine, compared with $31.8 \mu \mathrm{g}$. from the controls. The goitrogenic effect of living in the Vale of Glamorgan cannot therefore be directly attributed to the low iodine content of the water supply.

TABLE VI

RESULTS OF THE ANALYSIS OF WATER SAMPLES FOR IODINE CONTENT

\begin{tabular}{|c|c|c|c|c|c|c|}
\hline Area & $\begin{array}{l}\text { Type of } \\
\text { Water } \\
\text { Supply }\end{array}$ & \multicolumn{4}{|c|}{ Source of Sample } & $\begin{array}{c}\text { Iodine } \\
\text { Content } \\
\text { ( } \mu \mathrm{g} . / \text { litre })\end{array}$ \\
\hline \multirow{3}{*}{$\begin{array}{l}\text { Vale of } \\
\text { Glamor- } \\
\text { gan }\end{array}$} & Rain & House near Cowb & ge & . & . & $1 \cdot 9$ \\
\hline & Wells & $\begin{array}{lc}\text { Pendoylan } & \ldots \\
\text { Llancarfan } & \ldots \\
\text { Llantrithyd } & \ldots \\
\text { St. Hilary } & \ldots \\
\text { St. Mary Church } \\
\text { Llandow } & \ldots \\
\text { Treoes .. } & \ldots \\
\text { Llangan } & \ldots \\
\text { Llysworney } & \ldots \\
\text { St. Nicholas } & \ldots \\
\text { Coychurch } & \ldots \\
\text { Wick .. } & \ldots \\
\text { Llanharry } & \ldots \\
\text { Cowbridge } & \ldots \\
\text { Llanblethian } & \ldots \\
\text { Ystradowen } & \ldots\end{array}$ & $\begin{array}{l}\ldots \\
\cdots \\
\cdots \\
\cdots \\
\cdots \\
\ldots \\
\ldots \\
\cdots \\
\cdots \\
\cdots \\
\cdots \\
\cdots \\
\cdots\end{array}$ & $\begin{array}{l}\cdots \\
\cdots \\
\cdots \\
\cdots \\
\cdots \\
\cdots \\
\cdots \\
\cdots \\
\cdots \\
\cdots \\
\cdots \\
\cdots\end{array}$ & $\begin{array}{l}\ldots \\
\cdots \\
\cdots \\
\cdots \\
\cdots \\
\cdots \\
\cdots \\
\cdots \\
\cdots \\
\cdots \\
\cdots \\
\cdots\end{array}$ & $\begin{array}{l}4 \cdot 69 \\
3 \cdot 04 \\
2 \cdot 24 \\
2 \cdot 84 \\
3 \cdot 38 \\
3 \cdot 61 \\
2 \cdot 27 \\
3 \cdot 27 \\
2 \cdot 8 \\
1 \cdot 85 \\
2 \cdot 6 \\
5 \cdot 3 \\
3 \cdot 4 \\
0 \cdot 3 \\
3 \cdot 6 \\
2 \cdot 2\end{array}$ \\
\hline & Mains & \multicolumn{4}{|c|}{ 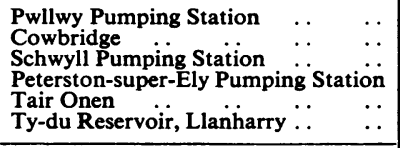 } & $\begin{array}{l}3 \cdot 55 \\
3 \cdot 8 \\
4 \cdot 35 \\
1 \cdot 2 \\
1 \cdot 15 \\
2 \cdot 7\end{array}$ \\
\hline \multirow[b]{2}{*}{$\begin{array}{l}\text { Other } \\
\text { Areas }\end{array}$} & Wells & \multicolumn{4}{|c|}{$\begin{array}{l}\text { Freshwater East, Pembroke ... } \\
\text { Beulah, Nr. Builth, Brecon ... } \\
\text { Llandovery, Carmarthen } \\
\text { Astwood Bank, Nr. Redditch } \\
\text { Melton Mowbray } \ldots \\
\text { Cork, Eire (River lee) } \quad \text {.. } \\
\end{array}$} & $\begin{array}{l}4 \cdot 6 \\
1 \cdot 2 \\
2 \cdot 25 \\
5 \cdot 5 \\
2 \cdot 8 \\
2 \cdot 8\end{array}$ \\
\hline & Mains & \multicolumn{4}{|c|}{ 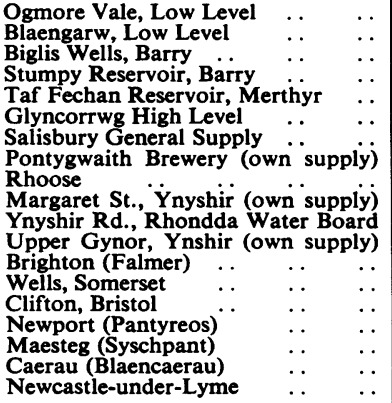 } & $\begin{array}{l}0 \cdot 3 \\
0 \cdot 0 \\
4 \cdot 9 \\
0 \cdot 4 \\
1 \cdot 5 \\
1 \cdot 6 \\
5 \cdot 1 \\
0 \cdot 9 \\
0 \cdot 9 \\
2 \cdot 45 \\
0 \cdot 75 \\
0 \cdot 4 \\
4 \cdot 0 \\
1 \cdot 9 \\
3 \cdot 7 \\
1 \cdot 1 \\
0 \cdot 0 \\
0 \cdot 0 \\
3 \cdot 6\end{array}$ \\
\hline
\end{tabular}

(6) Iodine from Other Sources.-Complete assessment of iodine intake was not attempted, since the period when this would have been most relevant was presumably in the years during which the goitre was developing. Instead, a very simple retrospective enquiry was made about the past consumption of three foodstuffs with a high iodine content; fish, shellfish, and laver-bread. The most emphatic replies to this inquiry came from those who denied they had ever eaten the foodstuff in question. It seems likely that the accuracy of this denial would be about the same in the goitre and control groups.

Table VII (overleaf) shows that the consumption of shellfish and laver-bread was approximately the same in the goitre and control groups. The goitre groups, however, contained an excess of persons who said they had never eaten fish. In the group with large goitres this excess is not quite significant, but testing by $\chi^{2}$ reveals that, among the whole group of thyroid abnormalities, there was a significant excess of those who stated that they never ate fish as compared with the control group. If, as we believe, neither the subject nor the questions were particularly biased in this direction, it must be accepted that there is a negative association between fish consumption and the development of thyroid abnormalities.

An approximate estimate of what this difference in fish consumption is likely to mean in terms of iodine intake can be made by assuming an average consumption per meal of $4 \mathrm{oz}$., containing $94 \cdot 3 \mu \mathrm{g}$. iodine. On this basis the mean weekly intake of iodine from fish works out at $45.4 \mu \mathrm{g}$. for the women with large goitres, and $76 \cdot 8 \mu \mathrm{g}$. for their matched controls. The difference between these mean intakes is just significant if a one-sided test is made. The mean iodine intakes of the two groups from shellfish and laver-bread were not significantly different. The importance of laver-bread as a source of iodine is particularly difficult to assess, since it was consumed by only a few subjects, and then in an erratic manner; such sudden large intakes of iodine cannot necessarily be equated physiologically with the same amount of iodine consumed at an even daily rate.

\section{Discussion}

(1) Methodology.-The technique used in this survey seems a satisfactory one for the investigation of the factors influencing the occurrence of goitre within a small defined area. It differs from the usual method employed in goitre surveys, by which the prevalence of goitre is determined in comparable populations (generally schoolchildren) living in different areas. The latter method has been useful in demonstrating the effect of iodine deficiency as the principal factor in deciding the overall incidence of goitre in various parts of the world. It is obvious, however, that many other factors may be involved in determining which individuals develop goitre within an area where, say, the prevalence is 10 or 20 per cent. The present survey was designed in the hope of finding indications of what factors are likely to be important in the individual. The essential feature of 
TABLE VII

NUMBER OF FEMALES CONSUMING FISH, SHELLFISH, AND LAVER-BREAD IN THE YEARS BEFORE THE DEVELOPMENT OF GOITRE

\begin{tabular}{|c|c|c|c|c|c|c|c|c|c|c|}
\hline \multirow[b]{2}{*}{ Diagnosis } & \multirow[b]{2}{*}{ Group } & \multicolumn{3}{|c|}{ Fish } & \multicolumn{3}{|c|}{ Shellfish } & \multicolumn{3}{|c|}{ Laver-Bread } \\
\hline & & Never & $\begin{array}{l}\text { Less than } \\
\text { Once a } \\
\text { Week }\end{array}$ & $\begin{array}{c}\text { Once a } \\
\text { Week or } \\
\text { More }\end{array}$ & Never & $\begin{array}{l}\text { Less than } \\
\text { Once a } \\
\text { Week }\end{array}$ & $\begin{array}{l}\text { Once a } \\
\text { Week or } \\
\text { More }\end{array}$ & Never & $\begin{array}{l}\text { Less than } \\
\text { Once a } \\
\text { Week }\end{array}$ & $\begin{array}{l}\text { Once a } \\
\text { Week or } \\
\text { More }\end{array}$ \\
\hline \multirow{2}{*}{ Large Goitre } & Goitre & 12 & 4 & 11 & 24 & 2 & 1 & 25 & 0 & 2 \\
\hline & Control & 5 & 4 & 18 & 23 & 2 & 2 & 24 & 1 & 2 \\
\hline \multirow{2}{*}{ All Thyroid Abnormalities .. } & Goitre & 45 & 17 & 62 & 110 & 10 & 4 & 112 & 8 & 4 \\
\hline & Control & 25 & 22 & 77 & 105 & 10 & 9 & 98 & 14 & 12 \\
\hline
\end{tabular}

the technique used here was the completely unbiased selection of paired controls, picked out at random from people living in the same area. An undoubted drawback of the method is its wastefulness, since it involves the rejection of all goitre-control pairs in which the control's thyroid is found, on examination, to be abnormal. It would of course have been possible to select fresh controls, provided one could be sure that to do so would not introduce bias. There does not seem to be any obvious reason why this should happen, yet we were deterred by the very size of the rejection-rate, amounting to 43 per cent. of the controls. If further controls were selected, and 43 per cent. of these had to be rejected and the whole process then repeated several times, the total number of subjects to be examined would have become unmanageable; and we should probably have been left with some doubts about the random nature of the sample selected in this cumbersome way. For these reasons we made use of only those goitre-control pairs in which the control's thyroid seemed normal at the primary examination. The wastage of material owing to unsatisfactory controls means that the technique is only applicable to areas with a medium prevalence of goitre. In those with a low prevalence it would not be possible to collect an adequate number of goitre cases; whereas in those with a high prevalence the number would also be limited by the large number of controls which would have to be rejected owing to the presence of a palpable thyroid.

It became apparent during this work that any goitre survey is subject to two severe limitations. One is the lack of any objective method of estimating thyroid size in the living subject. Before embarking on further field work it would seem highly desirable for any future investigator to devote some time to attempting to overcome this difficulty. The second limitation is imposed by the prolonged "incubation period" of goitre. It seems to us that investigation of the current dietary or other habits of persons with established goitre may well be irrelevant, for those habits may have changed radically since the period (it may be many years previously) when the goitre was actively growing. The present survey suffered from all the handicaps associated with retrospective inquiries. The goitrogenic influences which were evidently operating in the Vale of Glamorgan 20 years or so ago may no longer be active. This thought has discouraged us from pursuing the present investio gation any further.

(2) RESULTS.-Our results show that goitre is asso ciated with long residence in the Vale of Glamorgan. Current views on its aetiology would suggest that this observation might be explained by the low iodine content of the local water supply (Murray, Ryle, Simpson, and Wilson, 1948), but this explanation is not borne out by our findings. Most of the waters consumed by our subjects had a low iodine content; but so also did those consumed during residence outside the Vale (Table VI). Direct calculation showed that those with large goitres did not obtain any lesser quantity of iodine, on the average, from water than their matched controls. Moreover, the water with the highest iodine content $(5 \cdot 5 \mu \mathrm{g}$./litre) would have provided no more than about $11 \mu \mathrm{g}$. iodine per day, which seems a small proportion of the total of about $150 \mu \mathrm{g}$. per day usually consumed by people living in areas free from endemic goitre (Riggs, 1952). In communities more isolated and primitive than that studied by us, the iodine content of the water supply may have had a greater effect, since the water drunk directly by any indivudual would probably come from the same source as supplied his cabbages and his cows. Under present-day conditions, and even at the time when our subjects' goitres were growing, most types of foodstuff come from outside the immediate neighbourhood and their iodine content would not 
necessarily reflect that of the water used by the household for drinking purposes.

The subjects who developed goitre may have received inadequate quantities of iodine in their diets. Our data suggests that this was so, for those with goitre seem to have eaten less fish than their matched controls. Our data only extend to high iodine foods and do not tell us whether other, more subtle, differences in dietary habits may have further reduced the iodine intake of those who developed goitre. The data on the familial incidence of goitre might also be explicable on the basis of dietary habits, since the diets of the members of a family would tend to be similar.

Our findings suggest that variations in dietary habits are a factor in the causation of goitre, in so far as they modify iodine intake. The differences observed were, however, not sufficiently large or firmly demonstrated to enable us to explain individual variations in susceptibility to goitre entirely on this basis. An example which suggests that individual choice of foodstuffs is not the whole explanation can be found in O'Shea's investigation of a goitrous area in Southern Tipperary (O'Shea, 1946). She made complete studies of the iodine intake of families living in this area, and showed very clearly that it was considerably lower than that of comparable families in goitre-free Galway. Circumstances in Ireland were in one way favourable for this type of investigation, in that the diet of the poorer people was extremely limited in variety and offered no scope for the expression of individual preference. Yet, within the area of investigation in Tipperary, only a proportion of the population developed goitre, although the dietary intake of iodine was fairly uniform. Even within families, only some members would be affected although their intake was not obviously different from that of their goitre-free relatives (O'Shea, Personal communication). O'Shea's findings seem to suggest that, in Tipperary, the individual incidence of goitre is not determined merely by variation in the dietary intake of iodine. Other factors are evidently operating, but neither her work nor ours prcvides any suggestions as to what they may be.

\section{SUMmary}

(1) The number of persons with goitre living within a defined area in South Wales was ascertained. They were then compared with matched controls whose thyroids were normal to palpation, selected at random from the same population. The object was to ascertain the factors determining the individual incidence of goitre within a population exposed to a fairly uniform environment.

(2) Those with goitre had lived longer in the Vale of Glamorgan than the controls.

(3) There was a higher prevalence of goitre in the sibs, parents, and children of those with goitre. The prevalence in sibs was no greater than that in parents, and there was no excess of parental consanguinity.

(4) The intake of iodine from drinking water appeared to be the same in those with and without goitre. The controls had obtained more iodine from fish than the subjects with goitre. The consumption of other high-iodine foods (shellfish, laver-bread) was about the same in the two groups.

It is suggested that food habits, in so far as they affect iodine intake, may partly determine the individual prevalence of goitre. Other factors are probably also involved.

We are most grateful to Dr. John Gilson, Mr. Peter Oldham, and Dr. Dagmar Wilson for help and advice; and to the Water Engineers of numerous Water Boards and Borough and Urban District Councils for their kindness in sending us samples of the local water supply.

\section{REFERENCES}

Cochrane, A. L., Miall, W. E., and Clarke, W. G. (1956). Tubercle, 37, 417.

Davies, I. J., and Rogers, L. (1940). Brit. med. J., 1, 764.

Martin, L., and Fisher, R. A. (1945). Quart. J. Med., 14, 207. (1951). Ibid., 20, 293.

Murray, M. M., Ryle, J. A., Simpson, B. W., and Wilson, D. C. (1948). Medical Research Council Memorandum No. 18.

O'Shea, E. M. (1946). Irish J. med. Sci., 6th series, No. 251, p. 749.

Riggs, D. S. (1952). Pharmacol. Rev., 4, 284. 